\title{
THE USE OF MANDAMUS TO REVIEW REFERENCES TO SPECIAL MASTERS
}

Rule 53 of the Federal Rules of Civil Procedure authorizes district court judges, in appropriate circumstances, to refer the whole or any part of a case for hearing before a master. ${ }^{1}$ It is obvious that a proper reference is likely to achieve quite desirable ends. ${ }^{2}$ For example, the master usually has special competence in the type of litigation referred. In addition, the informality of the proceedings makes trial preparation less arduous and facilitates the disposition of complex issues. On the other hand, however, there are also obvious disadvantages in the use of a master, the most burdensome of which are the increases in trial cost and trial time that invariably attend a reference. ${ }^{3}$ Accordingly, orders of reference are often resisted by at least one party to the litigation. 4

Any attempt to review immediately an order of reference, however, is complicated by the fact that only certain interlocutory orders issued

\footnotetext{
${ }^{1}$ In general, the rule provides that each district court "may appoint one or more standing masters for its district, and the court in which any action is pending may appoint a special master therein." The rule also indicates broadly the circumstances which will justify reference to a special master [see nate I 6 infra], and prescribes the powers with which such masters shall be invested. See Dobie, The Federal Rules of Civil Procedure, 25 VA. L. REv. 261, 291-93 (1939); Strichartz, Masters and Their Fees, 3 Miami L.Q. 403 (1949).

${ }^{2}$ It has been suggested that reference to a special master is most appropriate in actions involving complicated issues of a specialized or technical nature. See Yankwich, "Short Cuts" in Long Cases, I3 F.R.D. 4I, 57, 79-81 (195I); Comment, 59 YALE L.J. II7, I32-34 (r949). Accordingly, masters have been utilized in actions for patent infringement to determine complex issues, Skinner v. Aluminum Co. of America, 95 F. Supp. I83, I84 (W.D. Pa. 195I), or to ascertain damages, Modern Art Printing Co. v. Skeels, I23 F. Supp. 426 (D.N.J. 1954). Cf. Zenith Radio Corp. v. Dictograph Products Co., 6 F.R.D. 597, 599 (D.Del. I947). Similarly, references have been made to determine the amount of unpaid wages and overtime under the Fair Labor Standards Act. Harrington v. Empire Construction Co., 7 I F. Supp. 324 (D. Md. 1947).

${ }^{3}$ See Adventures in Good Eating v. Best Places to Eat, I3I F.2d 809, 815 (7th Cir. 1942): "It is a matter of common knowledge that references greatly increase the cost of litigation and delay and postpone the end of litigation." Cf. Los Angeles Brush Mfg. Co. v. James, 272 U.S. 701, 707 (1927).

'See, e.g., Slatcoff v. Dezen, 74 So.2d 59 (Fla. 1954), noted in 9 Miami L.Q. $36 \times(1955)$.
} 
in the federal courts are appealable. ${ }^{5}$ Because of the final judgment rule, ${ }^{6}$ review of other orders may be had only through one of the extraordinary writs. ${ }^{7}$ Recently, the Supreme Court has granted certiorari to the Court of Appeals for the Seventh Circuit for review of a decision which involves the use of the writ of mandamus to obtain review of orders of reference to a special master. In Howes Leather Co. v. LaBuy, ${ }^{8}$ petitioners, defendants in an antitrust action which was referred to a master, sought a writ of mandamus to compel District Judge LaBuy to rescind the order of reference. ${ }^{9}$ The principal reasons advanced as a basis for the reference were the element of accounting involved, the congested condition of the court calendar, and the complexity of the issues in the case. ${ }^{10}$ The court of appeals held that the writ of mandamus should issue, concluding that the justification offered to support the reference was so inadequate as to make the reference not merely an erroneous decision, which should be corrected only on final

${ }^{5} 65$ STAT. 726 (1951), 28 U.S.C. § 1292 (1952). This statutory codification of the "final judgment rule" provides generally that four groups of interlocutory decrees may be appealed: ( 1 ) orders of the federal district courts granting, modifying, continuing, refusing or dissolving injunctions, except where a direct review by the Supreme Court is available; (2) orders appointing receivers or refusing to wind up receiverships; (3) decrees determining the rights and liabilities of the parties to admiralty cases; and (4) judgments in civil actions for patent infringment whicls are final except for accounting.

- The final judgment rule is grounded in certain practical considerations, sucl as avoidance of the delay and expense occasioned by fragmentary appeals, the aclievement of uniformity and certainty of judicial administration for litigants, and the desire to terminate litigation expeditiously. In addition, absent any restraints afforded by the rule, the appellate courts might be harassed with appeals. Sce generally, Crick, The Final Judgment as a Basis for Appeal, 41 Y YLE L.J. 539 (1932); Note, 58 YALE L.J. 1186, I187 (1949). As to the codification of the rule by statute in several states, see Note, 1940 Wrs. L. REv. 579, 583 .

"The "all writs statute," 63 STAT. 102 (1949), 28 U.S.C. $\S_{1651}$ (1952), provides that, "The Supreme Court and all courts established by Act of Congress may issue all writs necessary or appropriate in aid of their respective jurisdictions and agreeable to the usages and principles of law."

${ }_{226}$ F.2d 703 (7th Cir. 1955), cert. granted, 24 U.S.L. WEEK 3221 (U.S. Feb. $28,1956)($ No. 622).

- Actually, there were two petitions for writs of inandamus which arose out of two related actions pending before Judge LaBuy. In William Rohlfing ข. Cat's Paw Rubber Co., Civil No. 50-C-229, N.D. Ill., the parties had appeared before the inaster prior to the filing of the petition for a writ of mandamus. In Shaffer $\%$. United States Rubber Co., Civil No. 50-C-884, N.D. III., the petition was filed before the master's hearing convened.

${ }^{10} 226$ F.2d at 706. 
appeal, but an abuse of discretion, which could be corrected by the issuance of the writ. ${ }^{11}$

The cardinal limitation to be observed in the use of mandamus, as well as the other extraordinary writs, is that it must not be employed merely as a substitute for an unavailable interlocutory appeal. ${ }^{12}$ Consistent with this limitation, the scope of the writ has been only cautiously expanded; but, whereas originally it was available only to compel the performance of ministerial functions by public officials, now it may issue to compel an exercise of discretion or to review an abuse of discretion. ${ }^{13}$ Since, in the case of references to a special master, mandamus can serve only to review abuses of discretion, ${ }^{14}$ it would seem that the question of whether or not the writ may issue should depend upon the egregiousness of the error committed by the lower court in ordering the reference.

If, then, the crucial question is whether the severity of the lower court's error amounts to an abuse of discretion, it is necessary to determine within what permissible limits of discretion the court may order a reference. Since the main function of a master is to bring a special competence to certain types of litigation, it would seem that a reference

\footnotetext{
11226 F.2d at 707 .

12 "Mandaimus is not a substitute for, and cannot be used as an appeal or writ of error." State ex rel. Gresham v. Delaney, 213 Minn. $217,219,6$ N.W.2d 97, 98 $(1942)$. See also Bankers Life and Cas. Co. v. Holland, 346 U.S. 379,383 (1953); Ex parte Fahey, 332 U.S. 258, 260 (1947); Roche v. Evaporated Milk Ass'n, 319 U.S. 21, 27 (1943); Alcoa S.S. Co. v. Ryan, 2 I I F.2d 576, 577 (2d Cir. 1954); Gulf Research and Development v. Harrison, 185 F.2d 457, 459 (9th Cir. 1950); Federal Savings and Loan Ins. Corp. v. Reeves, 148 F.2d 731, 732 (8th Cir. 1945); Dilling v. U.S., 142 F.2d 473 (D.C. Cir. 1944).

${ }^{13}$ At common law, the writ of mandamus was a prerogative remedy, issued in the name of the sovereign, to compel public officials or inferior courts to exercise ministerial or judicial powers vested in them. It subsequently evolved into a judicial remedy, taking the form of a civil action at law. Although it remains an extraordinary legal remedy, the propriety of its discretionary issuance is determined by general equitable principles. See Crick, supra note 5; Note, so CoLUM. L. REv, I 102, I 104 (1950). As to the scope of mandamus in the federal courts, Justice Strong, in Virginia v. Rives, roo U.S. 313, 323 (1879), opined: “[I]t may be said to be an established remedy to oblige inferior courts and magistrates to do that justice which they are in duty, and by virtue of their office, bound to do. It does not lie to control judicial discretion, except when that discretion has been abused; but it is a remedy when the case is outside of the exercise of this discretion, and outside the jurisdiction of the court or officer to which or to whom the writ is addressed." See also, State ex rel. Gresham v. Delaney, 213 Minn. 217, 219, 6. N.W.2d 97, 98 (1942); Hilmer v. Superior Court, 220 Cal. 7r, 29 P.2d 175 (1934); Swanson v. Alworth, r 59 Minn. 193, 198 N.W. 453 (1924).

${ }^{14}$ See cases cited in note 12 supra.
} 
should be made only when the nature of the issues involved in a case make it reasonably necessary to take advantage of that special competence. ${ }^{15}$ Accordingly, Rule 53(b) suggests that there shall be a reference only when the issues are sufficiently specialized and complex. ${ }^{10}$ The only other guidance supplied by the rule is the admonition that a reference "shall be the exception and not the rule," and the direction that more exceptional conditions should be required to sustain a reference in nonjury cases than in jury cases. In the light of these imprecise standards, it is difficult to imagine many instances in which reference orders could be so erroneous as to be abusive of discretion.

Perhaps one such instance occurred in McCulloch v. Cosgrave, ${ }^{17}$ where the Supreme Court, per curiam, granted mandamus to rescind a reference order whose primary basis appeared to be the trial judge's illness and the impatience of the parties to terminate the litigation. ${ }^{18}$ Similarly, mandamus has been issued to compel a rescission of a reference order which was based on the practice of the district judge to refer all cases in a certain field of law to a master. ${ }^{10}$ In the LaBuy case, however, where there was an element of accounting involved, ${ }^{20}$ the court's calendar was congested, and the trial judge found the issues in the case to be complex, it would appear that the court of appeals'

\footnotetext{
${ }^{25}$ See note 2 supra.
}

${ }^{10}$ Rule ${ }_{53}$ (b) provides that, "A reference to a master shall be the exception and not the rule. In actions to be tried by a jury, a reference shall be made only when the issues are complicated; in actions to be tried without a jury, save in matters of account, a reference shall be made only upon a showing that some exceptional condition requires it."

${ }^{17} 309$ U.S. 634 (1940).

${ }^{18}$ The only case cited in tbe per curiam opinion was Los Angeles Brush Mfg. Co. ข. James, 272 U.S. 701 $(1927)$, wherein the district court judge, pursuant to a practice of referring all patent cases to special masters, issued an order of reference on the ground that the court's calendar was congested and that patent trials are lengthy. Although the Supreme Court in the James case refused to issue a writ of mandamus, it intimated that the presence of a congested calendar was not, in itself, an exceptional condition within the meaning of Rule $53(\mathrm{~b})$ and that a reference, issued solely on that basis, would in all probability be an abuse of discretion. 272 U.S. at 708. Cf. Skinner v. Aluminum Co. of America, 95 F. Supp. 183, 184 (W.D. Pa. 1951).

${ }^{10}$ E.g., United States v. Kirkpatrick, 186 F.2d 393 (3d Cir. 1951).

${ }^{20}$ This accounting element, however, did not constitute a "matter of account" under Rule 53(b). A liability to account must be definitely established before a reference can be made solely on the strength of the accounting provision of Rule 53 (b); a potential or even probable accounting is not sufficient. Columbian Equipment Co. v. Mercantile Trust \& Deposit Co., 1 13 Fed. 23 ( $5^{\text {th }}$ Cir. 1902). Even established liability to account is not conclusive; it must be shown that the matter is complex. 5 MOOre, Federal Practice T 53.05 (2d ed. 1953). 
issuance of mandamus was prompted by purposes other than the correction of an abuse of discretion. Rather, the decision seems to reflect an inclination to afford an interlocutory review of reference orders which are, at worst, erroneous, not egregiously erroneous. ${ }^{21}$

This inclination probably stems from a recognition that, in the case of an erroneous reference, the parties are likely to suffer considerable hardship if the reference is not reversed until final appeal. ${ }^{22}$ But obviously, any considerations of hardship to the parties are technically irrelevant to the propriety of mandamus, since they are unrelated to those factors which determine the magnitude of the error. ${ }^{23}$ That expense and prejudice are likely to occur, however, is hardly disputable. Even in ordinary reference cases, both parties may expect a certain amount of trial delay and are likely to be assessed a portion of the master's fee. ${ }^{24}$ If the reference, on final appeal, is held erroneous, this

\footnotetext{
${ }^{21}$ Similarly, the Seventh Circuit has taken a liberal view with respect to the use of mandamus to review nonappealable orders of transfer under section $1404(a)$ of the

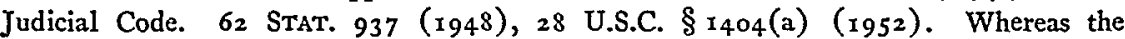
first, second, and third circuits issue mandamus only in "extraordinary circumstances," the seventh circuit, being more disposed to review of transfer orders, does not place an "extraordinary circumstance" limitation on the issuance of mandamus. Compare In re Josephson, 218 F.2d 174 (Ist Cir. 1954); Ford Motor Co. v. Ryan, I82 F.2d 329 (2d Cir. 1950), cert. denied, 340 U.S. 851 (1950); and All States Freight, Inc. v. Modarelli, r96 F.2d roso (3d Cir. 1952), with Chicago, R.I. \& Pac. R.R. v. Igoe, 220 F.2d 299 (7th Cir. 1955), cert. denied, 76 Sup. Ct. 49 (1955). See, Kaufman, Further Observation on Transfers Under Section ${ }_{4404}(a), 56$ CoLUM. L. REv. I, I-1 I (1956).

${ }^{22}$ See note 3 supra. Consider also the following cases: Forgay v. Conrad, 47 U.S. (6 How.) 653 (1847); Burgin v. Sugg, 2 10 Ala. 142, 97 So. 216 (1923).

${ }^{23}$ See Roche v. Evaporated Milk Ass'n, 319 U.S, 21,30 (1943): "[T] convenience is one which we must take it Congress contemplated in providing that only final judgments should be reviewable. Where the appeal statutes establish the conditions of appellate review, an appellate court cannot rightly exercise its discretion to issue a writ whose only effect would be to avoid those conditions and thwart the Congressional policy against piecemeal appeals in criminal cases." Cf. United States Alkali Export Ass'n v. United States, 325 U.S. 196, 202-03 (1945).

26 The determination as to which party will bear the burden of the master's compensation is made at the discretion of the trial court. The court may make its own allocation or accept an agreement between counsel. The only limitation on the court is that it act reasonably. Newton v. Consolidated Gas Co., 259 U.S. rox (1922). Therefore, the cost burden may fall on either party. See Heiberg v. Hasler, x F.R.D. 735. (E.D.N.Y. 194I) (upon defendant who requested the reference); General Motors Corp. v. Circulators \& Devices Mfg. Corp., 67 F. Supp. 745 (S.D.N.Y. 1946) (upon plaintiff at first, then taxed as part of plaintiff's cost against defendant); Los Angeles Brush Mfg. Co. v. James, 272 U.S. 701, 707 (1927); Adventures in Good Eating v. Best Places to Eat, 13 I F.2d 809, 815 (7th Cir. 1942). Cf. Helfer v. Corona Products, 127 F.2d 612, 614 (8th Cir. 1942).
} 
delay and expense are wasted. Furthermore, in certain cases, the cost of an erroneous reference may be imposed on one of the parties alone. ${ }^{25}$ For example, it has been held that the expense of an erroneous reference should be charged to the party who was instrumental in obtaining the reference. ${ }^{26}$ In addition, the compensation for special masters is customarily liberal, ${ }^{27}$ and the cases that are referred are those which typically promise to be the most protracted. ${ }^{28}$ Yet, regardless of the obvious relevance of these practical factors to the need for preliminary review, there appears to be no place for their consideration in the light of the formal principles governing the issuance of mandamus. ${ }^{20}$

Admittedly, the rationale underlying both the final judgment rule and the limitations on the use of mandamus is not to be wholly disregarded. However, when this rule and these limitations are the source of such inconvenience and prejudice to litigants that appellate courts are constrained to pay them only lip service, a re-examination of the need for full compliance would seem appropriate. Various proposals ${ }^{30}$ have been advanced to restrict the final judgment rule. Perhaps the reviewability of reference orders by mandamus, dependent as it is on a relatively unworkable criterion rather than on highly relevant practical considerations, ${ }^{31}$ illustrates the necessity that such proposals receive congressional attention.

${ }^{26}$ See 5 Moore, Federal Practice of 53.04(I) (2d ed. 1951), for cases cited in nn. $28-30$.

${ }^{26}$ Adventures in Good Eating v. Good Places to Eat, I3I F.2d 809 (7th Cir. 1942).

${ }^{27}$ In Newton . Consolidated Gas. Co., 259 U.S. 101, 105 (1922), the Supreme Court said that a high rate of pay is necessary to secure ability and experience in an exacțing and temporary employment. A rate of ten to twenty thousand dollars a year was said not to be too exorbitant. In Sheldon v. Metro-Goldayn Pictures Corp., 26 F. Supp. 134 (S.D.N.Y. 1938), the master was allowed compensation at the rate of $\$ 35$ per hour, plus \$250 per day for expenses; in Gold Seal Importers v. Morris White Fashions, 4 F.R.D. 386 (S.D.N.Y. 1945), the master was allowed $\$ 1500$ for eleven days; and in Clair v. Kastar, Inc., 7o F. Supp. 484 (S.D.N.Y. 1946), the master was allowed $\$ 2000$ for eighty-four hours. For a thorough discussion of compensation of a master, see 5 Moore, Federal Practice I 53.04 (2d ed. 1951). See also 3 MIAMI L.Q. 403, 410-13 (1949).

${ }^{28}$ See note 2 supra.

${ }^{20}$ See note 23 supra.

${ }^{30}$ For example: increase the number of interlocutory orders from which appeals may be taken; vest discretion in the trial or appellate courts to grant interlocutory appenls; provide for certified questions on interlocutory matters. See, generally, Moore and Vestal, Present and Potential Role of Certification in Federal Appellate Procedture, 35 VA. L. Rev. I, 45 (1949); Notes, 58 YALE L.J. I 86 (1949), 56 YALE L.J. 141 (1946). 38 Mich. L. REv. 208 (1939).

${ }^{3 x}$ See Roche v. Evaporated Milk Ass'n, 3 I9 U.S. 2I, 30-1 (1943). 